\title{
Front Matter: Volume 7649
}

, "Front Matter: Volume 7649," Proc. SPIE 7649, Nondestructive Characterization for Composite Materials, Aerospace Engineering, Civil Infrastructure, and Homeland Security 2010, 764901 (23 April 2010); doi: 10.1117/12.865245

Event: SPIE Smart Structures and Materials + Nondestructive Evaluation and Health Monitoring, 2010, San Diego, California, United States 


\section{PROCEEDINGS OF SPIE}

\section{Nondestructive Characterization for Composite Materials, Aerospace Engineering, Civil Infrastructure, and Homeland Security 2010}

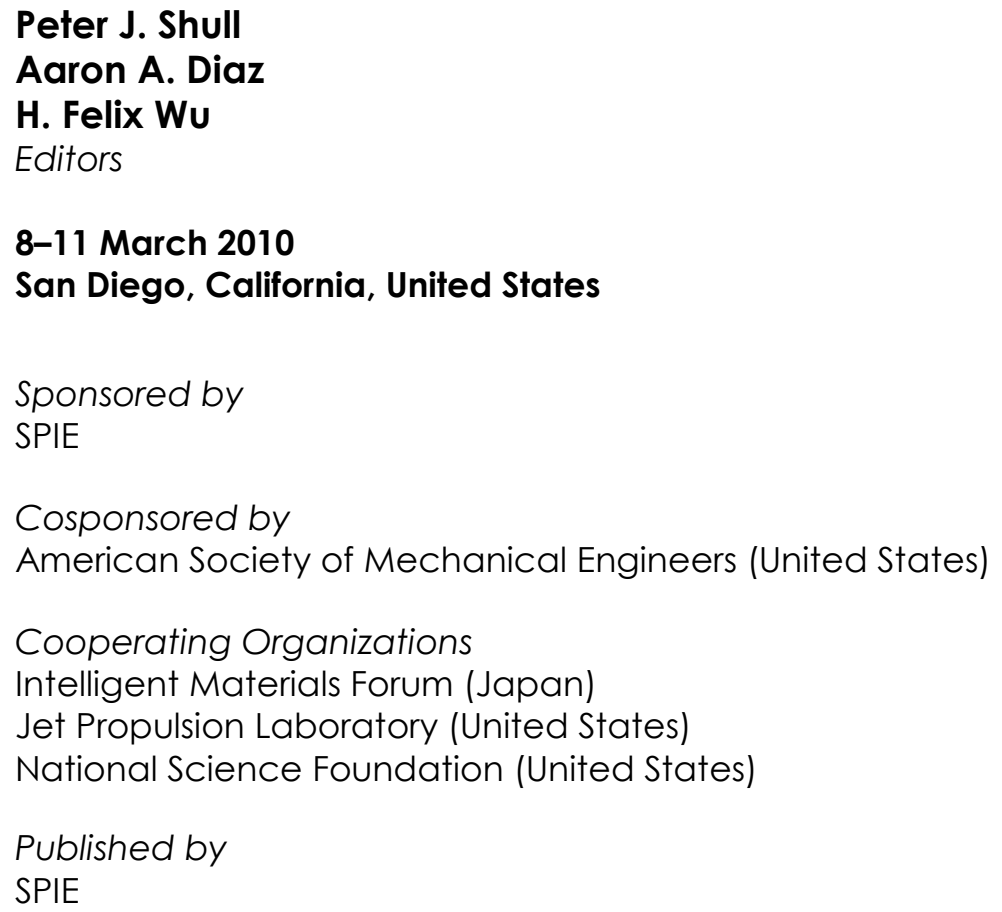


The papers included in this volume were part of the technical conference cited on the cover and title page. Papers were selected and subject to review by the editors and conference program committee. Some conference presentations may not be available for publication. The papers published in these proceedings reflect the work and thoughts of the authors and are published herein as submitted. The publisher is not responsible for the validity of the information or for any outcomes resulting from reliance thereon.

Please use the following format to cite material from this book:

Author(s), "Title of Paper," in Nondestructive Characterization for Composite Materials, Aerospace Engineering, Civil Infrastructure, and Homeland Security 2010, edited by Peter J. Shull, Aaron A. Diaz, H. Felix WU, Proceedings of SPIE Vol. 7649 (SPIE, Bellingham, WA, 2010) Article CID Number.

ISSN 0277-786X

ISBN 9780819480644

Published by

SPIE

P.O. Box 10, Bellingham, Washington 98227-0010 USA

Telephone +1 3606763290 (Pacific Time) · Fax +1 3606471445

SPIE.org

Copyright (C) 2010, Society of Photo-Optical Instrumentation Engineers

Copying of material in this book for internal or personal use, or for the internal or personal use of specific clients, beyond the fair use provisions granted by the U.S. Copyright Law is authorized by SPIE subject to payment of copying fees. The Transactional Reporting Service base fee for this volume is $\$ 18.00$ per article (or portion thereof), which should be paid directly to the Copyright Clearance Center (CCC), 222 Rosewood Drive, Danvers, MA 01923. Payment may also be made electronically through CCC Online at copyright.com. Other copying for republication, resale, advertising or promotion, or any form of systematic or multiple reproduction of any material in this book is prohibited except with permission in writing from the publisher. The CCC fee code is 0277-786X/10/\$18.00.

Printed in the United States of America.

Publication of record for individual papers is online in the SPIE Digital Library.

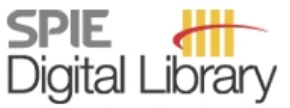

SPIEDigitalLibrary.org

Paper Numbering: Proceedings of SPIE follow an e-First publication model, with papers published first online and then in print and on CD-ROM. Papers are published as they are submitted and meet publication criteria. A unique, consistent, permanent citation identifier (CID) number is assigned to each article at the time of the first publication. Utilization of CIDs allows articles to be fully citable as soon they are published online, and connects the same identifier to all online, print, and electronic versions of the publication. SPIE uses a six-digit CID article numbering system in which:

- The first four digits correspond to the SPIE volume number.

- The last two digits indicate publication order within the volume using a Base 36 numbering system employing both numerals and letters. These two-number sets start with 00, 01, 02, 03, 04, $05,06,07,08,09,0 A, 0 B \ldots 0 Z$, followed by 10-1Z, 20-2Z, etc.

The CID number appears on each page of the manuscript. The complete citation is used on the first page, and an abbreviated version on subsequent pages. Numbers in the index correspond to the last two digits of the six-digit CID number. 


\section{Contents}

ix Conference Committee

\section{SESSION 1 OPTICAL METHODS FOR COMPOSITE AND CIVIL STRUCTURES I}

764902 Simultaneous strain and temperature measurement using long-period fiber grating sensors [7649-01]

G. Chen, H. Xiao, Y. Huang, Y. Zhang, Z. Zhou, Missouri Univ. of Science and Technology (United States)

764903 Impact localization on complex structures using FBG strain amplitude information [7649-02] C. Hiche, C. K. Coelho, A. Chattopadhyay, Arizona State Univ. (United States); M. Seaver, U.S. Naval Research Lab. (United States)

764904 A fiber Bragg grating interrogation system for health monitoring of metals and composites [7649-03]

A.-D. Nguyen, Los Gatos Research, Inc. (United States); A. S. Rakow, Stanford Univ. (United States)

\section{SESSION 2 OPTICAL METHODS FOR COMPOSITE AND CIVIL STRUCTURES II}

764907 Silicon-based thin film solid oxide fuel cell array [7649-77]

P.-C. Su, National Taiwan Univ. (Taiwan); F. B. Prinz, Stanford Univ. (United States)

764908 Casing pipe damage detection with optical fiber sensors: a case study in oil well constructions [7649-06]

Z. Zhou, Dalian Univ. of Technology (China) and Missouri Univ. of Science and Technology (United States); J. He, M. Huang, J. He, Harbin Institute of Technology (China); J. Ou, Dalian Univ. of Technology (China); G. Chen, Missouri Univ. of Science and Technology (United States)

764909 In situ monitoring of curing and ageing effects in FRP plates using embedded FBG sensors [7649-07]

G. Xian, C. Wang, H. Li, Harbin Institute of Technology (China)

7649 OA Structural health monitoring of PC structures with novel types of distributed sensors [7649-08] C. Yang, Southeast Univ. (China); Z. Wu, Southeast Univ. (China) and Jiangsu Transportation Research Institute (China); Y. Zhang, Jiangsu Transportation Research Institute (China)

\section{SESSION 3 HEALTH MONITORING OF AEROSPACE COMPOSITES}

7649 OC Fatigue damage prognosis of a cruciform structure under biaxial random and flight profile loading [7649-10]

S. Mohanty, A. Chattopadhyay, P. Peralta, D. Quech, Arizona State Univ (United States) 
7649 OD Lamb wave propagation in Z-pin reinforced co-cured composite pi-joints [7649-11] E. D. Swenson, S. R. Soni, Air Force Institute of Technology (United States); H. Kapoor, Virginia Polytechnic Institute and State Univ. (United States)

7649 OE Effects of Z-pins on Lamb waves in composite plates [7649-12]

E. D. Swenson, Air Force Institute of Technology (United States); H. Kapoor, Virginia Polytechnic Institute and State Univ. (United States); S. R. Soni, Air Force Institute of Technology (United States)

7649 OF Characterizing the self-sensing performance of carbon nanotube-enhanced fiber-reinforced polymers [7649-13]

B. R. Loyola, V. La Saponara, K. J. Loh, Univ. of California, Davis (United States)

7649 OG Analysis techniques for eddy current imaging of carbon fiber materials [7649-14] M. H. Schulze, N. Meyendorf, H. Heuer, Fraunhofer-Institut für Zerstörungsfreie Prüfverfahren (Germany)

SESSION 4 NIST TECHNOLOGY INNOVATION PROGRAM ON CIVIL INFRASTRUCTURE CRITICAL NATIONAL NEED: ADVANCED SENSING TECHNOLOGIES FOR THE INFRASTRUCTURE: BRIDGES, ROADS, HIGHWAYS, AND WATER SYSTEMS I

7649 OK A two-tiered self-powered wireless monitoring system architecture for bridge health management [7649-18]

M. Kurata, J. P. Lynch, T. Galchev, M. Flynn, Univ. of Michigan (United States); P. Hipley, California Dept. of Transportation (United States); V. Jacob, G. van der Linden, SC Solutions, Inc. (United States); A. Mortazawi, K. Najafi, R. L. Peterson, Univ. of Michigan (United States); L.-H. Sheng, California Dept. of Transportation (United States); D. Sylvester, Univ. of Michigan (United States); E. Thometz, California Dept. of Transportation (United States)

7649 OM Smart antenna technology for structural health monitoring applications [7649-20] T. Özdemir, Monarch Antenna, Inc. (United States); Y. Goykhman, Univ. of Michigan (United States); L. Oberdier, Monarch Antenna, Inc. (United States); J. Lynch, Univ. of Michigan (United States)

7649 ON Near-optimal sensor placement for health monitoring of civil structures [7649-21] G. W. van der Linden, A. Emami-Naeini, R. L. Kosut, H. Sederat, SC Solutions, Inc. (United States); J. P. Lynch, Univ. of Michigan (United States)

SESSION $5 \quad$ NIST TECHNOLOGY INNOVATION PROGRAM ON CIVIL INFRASTRUCTURE CRITICAL NATIONAL NEED: ADVANCED SENSING TECHNOLOGIES FOR THE INFRASTRUCTURE: BRIDGES, ROADS, HIGHWAYS, AND WATER SYSTEMS II

7649 OP Nondestructive monitoring of a pipe network using a MEMS-based wireless network [7649-23]

M. Shinozuka, Univ. of California, Irvine (United States); P. H. Chou, Univ. of California, Irvine (United States) and National Tsing Hua Univ. (Taiwan); S. Kim, Univ. of California, Irvine (United States); H. R. Kim, Ctr. for Embedded Software Technology (Korea, Republic of); E. Yoon, H. Mustafa, D. Karmakar, Univ. of California, Irvine (United States); S. Pul, Karadeniz Technical Univ. (Turkey) 
7649 OR Quantification of fatigue cracking in CT specimens with passive and active piezoelectric sensing [7649-25]

J. Yu, P. Ziehl, B. Zarate, J. Caicedo, L. Yu, V. Giurgiutiu, Univ. of South Carolina (United

States); B. Metrovich, Univ. of Miami (United States); F. Matta, Univ. of South Carolina (United States)

7649 OW Finite element analysis of surface wave radiation for pavement debonding [7649-83]

Y. LU, Y. Cao, Northeastern Univ. (United States); J. G. McDaniel, Boston Univ. (United States);

M. L. Wang, Northeastern Univ. (United States)

\section{SESSION 6 ACOUSTIC/ULTRASOUND CHARACTERIZATION I}

$76490 \mathrm{X}$ Fabrication and characterization of high frequency phased arrays for NDE imaging [7649-30]

X. Jiang, North Carolina State Univ. (United States); K. Snook, TRS Technologies, Inc. (United States); R. Liu, X. Geng, Blatek, Inc. (United States); W. S. Hackenberger, TRS Technologies, Inc. (United States)

7649 oY Evaluation of bridge cables corrosion using acoustic emission technique [7649-63]

D. Li, J. Ou, Dalian Univ. of Technology (China)

$7649 \mathrm{OZ}$ Ultrasonic inspection technique for NDE of fiber composite materials [7649-32]

D. Hentschel, F. Schubert, L. Schubert, B. Frankenstein, Fraunhofer-Institut für Zerstörungsfreie Prüfverfahren (Germany)

764910 Structural health monitoring techniques for detecting incipient buckling [7649-33]

K. Asamene, B. Ali, M. Sundaresan, North Carolina Agricultural and Technical State Univ. (United States)

764911 Service induced damage in composite laminates: non destructive assessment, quantification and modeling [7649-34]

D. G. Aggelis, N. M. Barkoula, T. E. Matikas, A. S. Paipetis, Univ. of loannina (Greece)

764912 Acoustic emission characterization of steel fibre reinforced concrete during bending [7649-35]

D. G. Aggelis, D. V. Soulioti, N. Sapouridis, N. M. Barkoula, A. S. Paipetis, T. E. Matikas, Univ. of loannina (Greece)

764913 Using 2-D arrays for sensing multimodal Lamb waves [7649-36]

M. Engholm, T. Stepinski, Uppsala Univ. (Sweden)

\section{SESSION 7 ACOUSTIC/ULTRASOUND CHARACTERIZATION II}

764914 Lamb wave excitation and detection with smart fasteners for structural health monitoring [7649-37]

H.-S. Yoon, R. DeCicco, Tennessee Technological Univ. (United States)

764915 Active learning data selection for adaptive online structural damage estimation [7649-38] D. Chakraborty, N. Kovvali, A. Papandreou-Suppappola, A. Chattopadhyay, Arizona State Univ. (United States) 
764918 Characterization of pitting corrosion on small diameter ductile iron pipe using thermography [7649-70]

Z. Liu, M. Genest, D. Krys, National Research Council Canada (Canada)

\section{SESSION 8 THERMOGRAPHIC IMAGING}

7649 1A Transient infrared thermography for damage evaluation in aerospace composites [7649-42] S. Pawar, K. Peters, North Carolina State Univ. (United States)

7649 1B Application of line scanning thermography for the detection of interlaminar disbonds in sandwich composite structures [7649-43]

O. Ley, Mistras Group (United States); S. Chung, J. Schutte, A. Caiazzo, Materials Sciences Corp. (United States); V. Godinez, Mistras Group (United States); B. Bandos, Naval Surface Warfare Ctr. (United States)

7649 1D Repair integrity monitoring of composite aerostructures using thermographic imaging [7649-45]

S. Grammatikos, E. Kordatos, N.-M. Barkoula, T. Matikas, A. Paipetis, Univ. of Ioannina (Greece)

\section{SESSION 9 WIRELESS RADAR NDE TECHNOLOGIES}

7649 1E A tunable impulse ultra-wide-band sensor for civil infrastructure sensing applications [7649-46]

J. W. Han, Danam Systems Inc. (Korea, Republic of); C. Nguyen, Texas A\&M Univ. (United States)

7649 IF A 35-GHz radar for sensing applications [7649-47]

J. S. Park, SAMSUNG Electronics Co. (Korea, Republic of); C. Nguyen, Texas A\&M Univ. (United States)

7649 IG Estimation of kernels mass ratio to total in-shell peanuts using low-cost RF impedance meter [7649-48]

C. V. Kandala, J. Sundaram, B. Hinson, National Peanut Research Lab. (United States)

\section{SESSION 10 CIVIL INFRASTRUCTURE HEALTH MONITORING I}

7649 1H Comprehensive condition assessment of bridge decks by multimodal NDE [7649-49] N. Gucunski, Rutgers, The State Univ. of New Jersey (United States); R. Feldmann, German Federal Institute for Materials Research and Testing (Germany); F. Romero, Rutgers, The State Univ. of New Jersey (United States); S. Kruschwitz, German Federal Institute for Materials Research and Testing (Germany); H. Parvardeh, Rutgers, The State Univ. of New Jersey (United States)

$764911 \quad$ A pragmatic and innovative approach for civil infrastructure management: structural behavior monitoring [7649-50]

G. Chen, Missouri Univ. of Science and Technology (United States) 
7649 1J Damage inspection of fiber reinforced polymer-concrete systems using a distant acoustic-laser NDE technique [7649-51]

T.-Y. Yu, Univ. of Massachusetts Lowell (United States); R. Haupt, MIT Lincoln Lab. (United States)

7649 IK The role of terrestrial 3D LiDAR scan in bridge health monitoring [7649-52]

W. Liu, S.-E. Chen, The Univ. of North Carolina at Charlotte (United States); A. Sajedi, FARO

Technologies Inc. (United States); E. Hauser, The Univ. of North Carolina at Charlotte (United States)

\section{SESSION 11 CIVIL INFRASTRUCTURE HEALTH MONITORING II}

7649 IL Identification and health monitoring of an instrumented building using earthquake response data [7649-53]

H. S. Ulusoy, M. Q. Feng, Univ. of California, Irvine (United States); P. J. Fanning, Univ. College Dublin (Ireland)

$76491 \mathrm{M}$ Structural behavior of a cable stayed bridge through the use of a long-term health monitoring system [7649-54]

Y. Cao, M. Wang, Northeastern Univ. (United States)

7649 IN Damage assessment of the bridge structures using a hybrid optimization strategy [7649-55]

R. Baghaei, M. Q. Feng, Univ. of California, Irvine (United States)

7649 1P Global mechanical behavior of Sutong Bridge under static loads [7649-64]

Y. B. Li, Q. W. Zhang, Tongji Univ. (China)

$76491 Q$ Segmentation of laser range image for pipe anomaly detection [7649-57]

Z. Liu, D. Krys, National Research Council Canada (Canada)

7649 IR Monitoring early age microstructure development of cement paste using bender elements [7649-58]

J. Zhu, S.-H. Kee, The Univ. of Texas at Austin (United States)

7649 is Efficient order reduction in vibration analysis of periodic structures with uncertainties

[7649-59]

Z. Xia, J. Tang, Univ. of Connecticut (United States)

7649 IT Damage detection of an in-service condensation pipeline joint [7649-60]

J. Briand, D. Rezaei, F. Taheri, Dalhousie Univ. (Canada)

$76491 \mathrm{~V}$ Ultrasonic wave attenuation measurement for nondestructive evaluation of concrete [7649-76]

H. J. Yim, KAIST (Korea, Republic of); J. H. Kim, Northwestern Univ. (United States); H.-G. Kwak, KAIST (Korea, Republic of)

\section{POSTER SESSION}

$76491 \mathrm{X} \quad$ Non-linear material characterisation using the noncollinear method [7649-65]

A. J. Croxford, P. D. Wilcox, B. W. Drinkwater, Univ. of Bristol (United Kingdom) 
764912 Analysis of monitored strain of the National Aquatics Center under snow load [7649-68] H. Li, F. Zhou, W. Zhou, Y. Zhu, J. Teng, Harbin Institute of Technology (China); J. Ou, Harbin Institute of Technology (China) and Dalian Univ. of Technology (China)

764920 The advanced magnetovision system for Smart application [7649-69]

J. Kaleta, P. Wiewiórski, D. Lewandowski, Wroclaw Univ. of Technology (Poland)

764922 Measurement of surface resistivity/conductivity of anodized aluminium alloy by optical interferometry techniques [7649-73]

K. Habib, Kuwait Institute for Scientific Research (Kuwait)

Author Index 


\title{
Conference Committee
}

\author{
Symposium Chairs \\ Donald J. Leo, Virginia Polytechnic Institute and State University (United \\ States) \\ Kara J. Peters, North Carolina State University (United States) \\ Symposium Cochairs
}

Norbert G. Meyendorf, Fraunhofer-Institut für Zerstörungsfreie Prüfverfahren (Germany)

Norman M. Wereley, University of Maryland, College Park (United States)

Conference Chair

Peter J. Shull, The Pennsylvania State University (United States)

Conference Cochairs

Aaron A. Diaz, Pacific Northwest National Laboratory (United States) H. Felix Wu, National Institute of Standards and Technology (United States)

Program Committee

A. Emin Aktan, Drexel University (United States)

Farhad Ansari, University of Illinois at Chicago (United States)

George Y. Baaklini, NASA Glenn Research Center (United States)

Lawrence Bank, National Science Foundation (United States)

Yoseph Bar-Cohen, Jet Propulsion Laboratory (United States)

Oral Buyukozturk, Massachusetts Institute of Technology (United States)

Fu-Kuo Chang, Stanford University (United States)

Steven Chase, University of Virginia (United States)

Howard Chung, Acellent Technologies, Inc. (United States)

Maria Q. Feng, University of California, Irvine (United States)

Masoud Ghandehari, Polytechnic Institute of New York University (United States)

Hamid Ghasemi, Federal Highway Administration (United States)

Nenad Gucunski, Rutgers, The State University of New Jersey (United States)

Andrew L. Gyekenyesi, NASA Glenn Research Center (United States)

Xiaoning Jiang, North Carolina State University (United States)

Garo K. Kiremidjian, Sensametrics, Inc. (United States) 
Amrita Kumar, Florida State University (United States)

Jerome P. Lynch, University of Michigan (United States)

Richard E. Martin, Cleveland State University (United States)

Theodore E. Matikas, University of loannina (Greece)

Paul Mlakar, U.S. Army Engineer Research and Development Center (United States)

Aftab A. Mufti, University of Manitoba (Canada)

Didem Ozevin, University of Illinois at Chicago (United States)

Masanobu Shinozuka, University of California, Irvine (United States)

Kurt L. Silvers, Pacific Northwest National Laboratory (United States)

Lizhi Sun, University of California, Irvine (United States)

Bernhard R. Tittmann, The Pennsylvania State University (United States)

Brian J. Tucker, Pacific Northwest National Laboratory (United States)

Dietmar W. Vogel, Fraunhofer-Institut für Zuverlässigkeit und

Mikrointegration (Germany)

Ming Wang, Northeastern University (United States)

Yang Wang, Georgia Institute of Technology (United States)

Tzu-Yang Yu, University of Massachusetts Lowell (United States)

Jian Zhang, Drexel University (United States)

Ying Zhang, Georgia Institute of Technology (United States)

Session Chairs

1 Optical Methods for Composite and Civil Structures I

Amrita Kumar, The Florida State University (United States)

Pei-Chen Su, National Taiwan University (Taiwan)

2 Optical Methods for Composite and Civil Structures II

Jerome P. Lynch, University of Michigan (United States)

Amrita Kumar, Florida State University (United States)

3 Health Monitoring of Aerospace Composites

Aditi Chattopadhyay, Arizona State University (United States)

Pei-Chen Su, National Taiwan University (Taiwan)

$4 \quad$ NIST Technology Innovation Program on Civil Infrastructure Critical National Need: Advanced Sensing Technologies for the Infrastructure:

Bridges, Roads, Highways, and Water Systems I

A. Emin Aktan, Drexel University (United States)

Nenad Gucunski, Rutgers, The State University of New Jersey (United States) 
$5 \quad$ NIST Technology Innovation Program on Civil Infrastructure Critical National Need: Advanced Sensing Technologies for the Infrastructure: Bridges, Roads, Highways, and Water Systems II

Nenad Gucunski, Rutgers, The State University of New Jersey (United States)

A. Emin Aktan, Drexel University (United States)

6 Acoustic/Ultrasound Characterization I

Xiaoning Jiang, North Carolina State University (United States)

Didem Ozevin, University of Illinois at Chicago (United States)

$7 \quad$ Acoustic/Ultrasound Characterization II

Xiaoning Jiang, North Carolina State University (United States)

Didem Ozevin, University of Illinois at Chicago (United States)

8 Thermographic Imaging

Ying Zhang, Georgia Institute of Technology (United States)

Genda Chen, Missouri University of Science and Technology (United States)

$9 \quad$ Wireless Radar NDE Technologies

Tzu-Yang Yu, University of Massachusetts Lowell (United States)

Ying Zhang, Georgia Institute of Technology (United States)

10 Civil Infrastructure Health Monitoring I

Ming L. Wang, Northeastern University (United States)

Tzu-Yang Yu, University of Massachusetts Lowell (United States)

11 Civil Infrastructure Health Monitoring II

Ming L. Wang, Northeastern University (United States)

Tzu-Yang Yu, University of Massachusetts Lowell (United States) 
Downloaded From: https://www.spiedigitallibrary.org/conference-proceedings-of-spie on 26 Apr 2023

Terms of Use: https://www.spiedigitallibrary.org/terms-of-use 